\title{
A shy hope in the heart? Religious journalism in Australia and the Kuyperian legacy
}

\author{
Pass, Bruce R \\ University of Edinburgh \\ brucepass@gmail.com
}

\begin{abstract}
This article explores points of contact between Abraham Kuyper's legacy in the field of religious journalism and the Centre for Public Christianity, an independent media company at the forefront of Australian religious journalism. While the cultural, political, and religious setting of twenty-first century Australia could not be further removed from that of late nineteenth century Netherlands, these two approaches to religious journalism hold much potential for mutual resourcement. The points of contact identified indicate the possibility that Kuyperian principle holds considerable explanatory power for the praxis of the Centre for Public Christianity, just as the praxis of the Centre for Public Christianity exposes underdeveloped elements of Kuyperian principle.
\end{abstract}

Key words

Religious journalism; Australia; Abraham Kuyper; ecclesiology

\section{Introduction}

That religion has never enjoyed a prominent place in Australian journalism can largely be attributed to the minimal place religion occupies in the Australian psyche. ${ }^{1}$ In the words of historian Manning Clark (1915-1991),

1 Sociological analysis of religion in Australia is a relatively recent phenomenon. The first comprehensive sociological study of religion in Australia was Hans J. J. Mol's Religion in Australia: A Sociological Investigation (Melbourne: Nelson, 1971), cit. Alan W. Black, "The Sociology of Religion in Australia," Sociological Analysis 51 Suppl. (1990): 27. Most studies of the place of religion in Australian society draw attention to the impact of its origins as a penal colony. The most recent analysis, Tom Frame's Losing $M y$ Religion: Unbelief in Australia (Sydney: UNSW Press, 2009), likewise draws attention 
religion in Australia is but "a shy hope in the heart." ${ }^{2}$ Even in light of this, Australian religious journalism has fallen on particularly hard times of late. With the retirement of Barny Zwartz in December 2013, Australia witnessed the departure of the last religion editor from the ranks of its major newspapers. To attribute this state of affairs entirely to a secularist bias of the mainstream media would, however, be mistaken. In the last twenty years journalism has undergone nothing short of a revolution. The advent of digital media has precipitated radical change in newspapers' business models, which in turn has brought about change in their form and content. ${ }^{3}$ Yet in spite of these challenges a new organization has arisen that

to the deleterious effect of this early association of religion with the disciplinary establishment, but also draws out a continuing indifference toward religion on the part of the generations that followed. While Frame's basic thesis can be affirmed, namely, that contemporary secularism should not be viewed as a radical declension from a particularly pious past, the historical narrative he constructs to make his point is somewhat imbalanced for the fact that it focuses on the absence of formalized religion on frontier territories and the more dissonant voices of the urban centers in the second half of the $19^{\text {th }}$ century. It is regrettable that Frame did not attend more closely to the reasons why it was, that, as he states, "anyone who refused to profess religious belief was consciously standing apart from society and popular culture" (Frame, 59). In this connection the colonial government's endorsement of a broadly Christianized, yet nonsectarian, society, as typified by the 1836 Church Act, deserves greater credence, cf. Stuart Piggin, "Power and Religion in a Modern State: Desecularisation in Australian history," The Journal of Religious History, 38/3 (2014): 320-40; Gregory Melleuish, "A Secular Australia?: Ideas, Politics and the Search for Moral Order in Nineteenth and Early Twentieth Century Australia," The Journal of Religious History, 38/3 (2014): 4012. Another weakness of Frame's analysis is the marginal attention paid to the impact of post-World War II and post-White Australia Policy patterns of immigration. In all fairness though, this still remains largely undocumented. Cf. Hilary M. Carey et al. "Australian Religion Review, 1980-2000, Part 1: Surveys, Bibliographies and Religions Other Than Christianity," The Journal of Religious History 24/3 (2000): 296. Nearly 25 years ago John Thornhill considered that it was still too early to accurately discern what this impact might be. Cf. John Thornhill, Making Australia: Exploring Our National Conversation, (Newtown: Millennium, 1992), 177. It may still be too early.

2 Manning Clark, "Heroes," in Australia: The Daedalus Symposium, ed. S. Graubard (London: Angus and Robertson, 1985), 77-8. Clark's phrase has held enduring appeal, most recently being taken up by Gary Bouma in his Australian Soul : Religion and Spirituality in the Twenty-First Century, (Cambridge: Cambridge University Press, 2006).

3 The most significant challenge felt by Australian newspapers was undoubtedly the drying up of their "rivers of gold", cf. Rodney Tiffen, "Australian Journalism," Journalism 10/3 (2009): 384-6. The loss of a monopoly on classified advertising precipitated significant changes in both the form and content of journalism. For an analysis of the "tabloidization" of Australia's broadsheets, cf. David Rowe, "Obituary for the newspaper? Tracking the tabloid," Journalism 12/4 (2011): 449-66. Beyond the financial aspects, the ability to track 'click rates' has allowed newspapers to gauge the 
has managed to keep the subject of religion in the Australian conversation. In the decade since its founding, the Centre for Public Christianity has reclaimed a place for religious journalism in the mainstream media. Attentive both to the digital environment it inhabits and the postChristian audience it seeks to address, the Centre for Public Christianity's writers and spokespersons feature regularly in Australian newspapers, radio, and television. Although the cultural, political, and religious setting of twenty-first century Australia could not be further removed from that of late nineteenth century Netherlands, certain points of contact may be observed between the work of the Centre for Public Christianity and the journalistic career of Abraham Kuyper. These points of contact hold relevance not only for contemporary reflection on the place of religious journalism in mainstream Australian media, but also for the work of the Centre for Public Christianity, as it continues to negotiate the increasingly broad scope of religious journalism in a digital age. In what follows, a brief sketch of the journalistic activities of the Centre for Public Christianity will be presented, before proceeding to an investigation of the points of contact with Kuyper's journalistic career, which arise from this sketch. The reciprocal constructive potential these points of contact hold will then be explored.

\section{The Centre for Public Christianity}

Founded in 2007 by John Dickson and Greg Clarke, the Centre for Public Christianity (hereafter CPX) is an independent and non-denominational media company that seeks to engage the public with a clear, measured, and respectful picture of the Christian faith, demonstrate the impact of Christianity in all of life for the common good, and present the broader public with a Christian perspective on contemporary life. ${ }^{4}$ The considerable success that the CPX has enjoyed in achieving these aims can largely to be attributed to the way the CPX has fully embraced the realities of communication in the digital age.

popular appeal of specific content, putting pressure on editors not to dedicate resources to articles that generate marginal readership.

4 Details concerning the activities and rationale of the CPX are drawn from an interview with CPX writer Natasha Moore and the website, www.publicchristianity.org/about. 
In its journalistic activities the CPX employs a strategy that not only skirts prohibitive editorial and production costs, but exposes its message to a genuinely mainstream audience. Accordingly, the CPX does not produce its own publication. Instead, its stable of writers submit articles to mainstream Australian newspapers and media hubs, such as The Sydney Morning Herald or the Australian Broadcasting Commission's Religion and Ethics Portal. ${ }^{5}$ Newspaper journalism and online publishing does not, however, constitute the CPX's sole mode of communication. Diversification is key to the CPX's communications strategy, as online newspapers make up only one of many modes of digital communication by which Australians source news and current affairs. ${ }^{6} \mathrm{CPX}$ representatives appear regularly as guests on high profile television programs such as $Q \& A$ and Sunrise, and radio broadcasts such as $2 U E$ and Radio National. ${ }^{7}$

While the CPX disseminates a wide range of original content by various modes of communication, it finds a centralized platform on a website, which engages a wider audience of 145 countries. ${ }^{8}$ That the CPX is aware of this international dimension is evident in the way in which it strives to engage not merely in public, but in global theology. This is exemplified

5 The advantages of this strategy quickly become apparent, if one compares the circulation of independent religious publications with the mainstream newspapers. For example the newspaper Eternity, produced by The Australian Bible Society, sustains a monthly circulation of 100 000, whereas the Sydney Morning Herald claims a daily readership of 4.8 million. www.biblesociety.org.au/meet-the-bible-society/our-publications/abouteternity/ Accessed 23.2.16 ; www.adcentre.com.au/brands/the-sydney-morning-herald/ Accessed 23.2.16. The Australian Broadcasting Corporation's Religion and Ethics portal, www.abc. net.au/religion/ (hereafter RE), was established in 2010 under the guidance of its current editor, Scott Stephens. The portal was established as one of six special interest webs pages alongside health, science, environment, disability, technology and games. The RE portal stands aside from the Australian online newspapers, insofar as its host, the federally funded Australian Broadcasting Commission, is not subject to the market imperative that drives the commercial industry. This frees the RE portal to pursue a much slower cycle of publication. One benefit of this for the CPX is that it is able to publish considerably more substantial articles through the RE that major online newspapers would never publish.

6 Cf. Reuters Institute Digital News Report 2015, 10-11. www.reutersinstitute.politics.ox.ac. uk/sites/default/files/Reuters\%20Institute\%20Digital\%20News\%20Report\%202015_Full\%20Report.pdf accessed 23.2.16.

7 www.abc.net.au/tv/qanda/txt/s3687812.htm;

www.au.tv.yahoo.com/sunrise/video/watch/29240501/ religion-in-schools-sparks-unholy-row/\#page1; www.abc.net.au/radionational/programs/spiritofthings/liftyour-spirits/6831282; www.2ue.com.au/ Accessed 23.2.16. www.publicchristianity.org 
in the events and conferences that the CPX sponsor, such as the annual Richard Johnson Lecture, whose inaugural was delivered by the founding director of the Yale Centre for Faith and Culture, Miroslav Volf, ${ }^{9}$ but it is also a hallmark of the CPX's in-house productions. The current flagship project, a video production scheduled for release mid-2017 entitled For the Love of God: How the Church is Better and Worse Than You Ever Imagined, features interviews with figures of international significance such as Marilynne Robinson, Nicholas Wolterstorff, Rowan Williams, and John Lennox. While there are obvious limitations on the degree to which any organization can foster national and international relevance, the CPX's attempt to engage in global theology both lifts the eyes of the Australian public above the horizon of its own culture and enhances the relevance of its material for the broader audience via the CPX website.

\section{Points of contact with Abraham Kuyper}

Even on such a cursory glance, several points of contact emerge between the CPX and Abraham Kuyper (1837-1920). This correspondence is made all the more remarkable for the fact that Australia is a country in which Neo-Calvinism has virtually no reception history. ${ }^{10}$ First, the CPX bears a striking semblance to Kuyper's ecclesiological conception of the church-asorganism. Second, like Kuyper's own journalism, the CPX is characterized by an awareness of its prophetic function in furnishing public debate with a reasoned Christian voice. ${ }^{11}$ Third, the CPX is well aware of an inherently political dimension to religious journalism. On closer inspection, however, these points of contact also reveal significant differences. For example, the CPX's focus on an educated elite stands in stark contrast with Kuyper's appeals to "de kleine luyden". Moreover, in contrast with Kuyper's rather combative style the CPX avoids a denunciatory tone and seeks to affirm

9 www.richardjohnson.com.au/ Accessed 23.2.16.

10 The Christian Reformed Church of Australia was formed in the wake of post-World War II migration of members of the Gereformeerde Kerken in Nederland and comprises around 50 congregations, cf. www.crca.org.au/about-the-crca/history.html Accessed 26.2.16. Willem Berends recounts abortive attempts over 50 years to establish something comparable to Kuyper's Vrije Universiteit, cf. Willem Berends, "Tertiary Education in Australia: Part II," Christian Higher Education, 11/5, (2012): 303-309.

11 Albertus Zijlstra, „Dr Kuyper als jouranlist,“ in Dr. A. Kuyper 1837-1937, ed. L. W. G. Scholten, C. Smeenk, and J. Waterink, (Kampen: Kok, 1937), 245-7, 259. 
what Christians and non-Christians hold in common. Significant points of difference are also evident in connection with the relationship to politics. Whereas De Standaard functioned as the virtual organ of Kuyper's AntiRevolutionary Party, the CPX deliberately avoids promoting the agenda of any single political platform.

While real, these points of difference do not necessarily reflect a fundamental divergence in principle. ${ }^{12}$ Kuyper himself held that singularity of principle does not entail singularity of praxis. Calvinistic principles in particular might be realized in quite diverse ways in differing historical contexts, because they embody a "life-system."13 In this regard, Kuyper's appraisal of his own historical context is highly relevant to whether or not these differences represent a fundamental divergence in principle. Kuyper viewed fin de siecle Netherlands as having arrived at what he regarded as a halfway point in an extended process of secularization or de-Christianization. Somewhat presciently Kuyper sensed that a more thoroughly de-Christianized future loomed beyond the immediate horizon. Kuyper did not, however, allow this putative future to shape the way he would seek to apply Calvinistic principles in the present. Rather, Kuyper tailored his public theology to the conditions of the half-way point he perceived himself to inhabit, all the while recognizing that the situation that threatened might necessitate a very different set of practices. ${ }^{14}$ It is an exaggeration to describe Australia in the words of the former Dean of Yale Divinity School, Colin Williams, as "the most secularized of all western cultures,"15 but contemporary Australian society unquestionably stands in

12 The CPX's founders Rev Dr John Dickson and Dr Greg Clarke are both graduates of Moore Theological College and broadly Calvinistic in outlook.

13 "This of itself excludes every idea of imitative repristination, and what the descendants of the old Dutch Calvinists as well as of the Pilgrim fathers have to do, is not to copy the past, as if Calvinism were a petrefact, but to go back to the living root of the Calvinistic plant, to clean and to water it, and so to cause it to bud and to blossom once more, now fully in accordance with our actual life in these modern times and with the demands of the times to come." Abraham Kuyper, Calvinism: Six Stone-Lectures (Edinburgh : T. \& T. Clark, 1899), 232.

14 Cf. Ad de Bruijne, "Colony of Heaven: Abraham Kuyper's Ecclesiology in the TwentyFirst Century," Journal of Markets and Morality 17/2 (2014): 456-8.

15 Cf. Douglas Millikan, "Christianity and Australian Identity," in The Shape of Belief ed. Harris et al (Homebush: Lander, 1982), 39. Martin Marty puts flight to this fancy when he writes, "Australians ordinarily find it important to start conversations on religion by saying something like, 'You know, we are the most secular society on earth.' ... [yet] 
closer relation to the future Kuyper anticipated than the present in which he lived and worked. Precisely how Abraham Kuyper would tailor his public theology to an Australian context is open to conjecture, but what is certain is that Kuyper would be unlikely to replicate the practises he had deemed fitting to his own nineteenth century Dutch context in twentyfirst century Australia. ${ }^{16}$ It is possible that Kuyper would even regard the CPX's reluctance to promote the agenda of any single political platform or comparative neglect of "the little people" as a prudent response to a culture that has progressed well beyond the half-way point of secularization of his beloved Netherlands.

The points of difference to be observed between Abraham Kuyper and the CPX therefore, do not necessarily indicate principal divergence, but neither would it be accurate to regard the CPX as a stray Kuyperian flower that has budded on foreign soil. ${ }^{17}$ Rather, these points of contact suggest that Kuyperian principle may hold considerable explanatory power for CPX praxis, just as CPX praxis may even raise pertinent questions for Kuyperian principle. To that end, the remainder of this paper will briefly explore the relevance of the praxis of the CPX for two elements of Kuyper's ecclesiology, namely, the organism-institution distinction and the doctrine pluriformity.

for some reason, the vast majority of Australians tell pollsters that they believe in God, in Jesus, in prayer ... Australians find it plausible and useful to subsidize with tax funds private schools of the sort we would call parochial: Anglican, Presbyterian, Catholic and the like ... Are these signs of a merely or utterly secular society?" Martin E. Marty, "Talking About Religion Down Under," The Christian Century, 106/23 (1989): 708-9.

16 As such, Kuyper's praxis could be characterized as a principled pragmatism, an idealism tempered by realities of the hour. James Bratt captures this well when he states, that [Kuyper] "was responding to his times and not simply proceeding by logical deduction from fixed principles. Certainly, he often invoked such principles, not least to bolster his authority or his followers' sense of security. But Kuyper argued that he practiced 'inductive' in contrast to his opponents' 'deductive' social thinking, and he was Burkean enough to disavow a priori ideologies, statesman enough to know the importance of practical wisdom in the exercise of his craft, and polemicist enough to know how to harness an abstract principle to serve the application of the moment." Cf. James Bratt, "Passionate About the Poor: The Social Attitudes of Abraham Kuyper," Journal of Markets and Morality 5/1 (2002): 36.

17 Vincent Bacote surely casts the net a little too wide when he states, that 'to be a Kuyperian today, we must understand the challenges of our era ... and develop theologically grounded approaches to public engagement' Cf. Vincent Bacote, The Spirit in Public Theology: Appropriating the Legacy of Abraham Kuyper (Eugene: Wipf and Stock, 2005), 155 . 


\section{The organism-institution distinction and the church's intrusive voice}

Organic ecclesiologies were commonplace in the early nineteenth century, especially those of a more Hegelian hue, yet Abraham Kuyper made an unique contribution to Protestant theology with his synthesis of the institutional and the organic as dual aspects of a single ecclesial reality. ${ }^{18}$ Kuyper's ecclesiology is by no means immune to criticism, ${ }^{19}$ but the organism-institution distinction warrants more charitable attention than it is often accorded, if only for the fact that it grasps the nettle of one of post-Modernity's more significant ecclesiological problems, namely, the place of the church within the State. Although Kuyper was admittedly more interested in the way the Dutch State was infringing the liberty of the church, the organism-institution distinction can be used fruitfully in delineating ways in which the institutional church could compromise the sovereignty of other spheres. This holds particular interest in connection with certain remarks in John Thornhill's insightful account of the place of religion in Australian society.

18 John Halsey Wood, Going Dutch in the modern age: Abraham Kuyper's struggle for a free church in the nineteenth-century Netherlands (New York, NY : Oxford University Press, 2013), 86.

19 The most recent exploration of the problematic elements of Kuyper's construct is Daniel Strange, "Rooted and Grounded? The Legitimacy of Abraham Kuyper's Distinction between Church as Institute and Church as Organism, and Its Usefulness in Constructing an Evangelical Public Theology," Themelios 40/3 (2015): 429-45. Strange can be commended in his probing of questionable aspects of Kuyper's typology, but his analysis is marred by several missteps. In particular, Strange seems to be unaware of remarkable similarities between Kuyper's ecclesiology and the ecclesiological model he presents an alternative, namely, the so-called Knox-Robinson ecclesiology. Specifically, Strange appears to be unaware that Kuyper defines the church as an earthly congregation which is the manifestation of a heavenly reality in (cf. Kuyper, Calvinism, 78, 81), and describes "gathering" as the essence of the church in his Tractaat van de Reformatie der Kerken (Höveker and Zoon: Amsterdam, 1883), 32, both of which are central tenets of the so-called Knox-Robinson ecclesiology to which he alludes in his citations of David Peterson, “The 'Locus' of the Church - Heaven or Earth?," Churchman 112/3 (1998): 199-213 and Peter Bolt, "Mission and Witness," in Witness to the Nations: The Theology of Acts, eds. D. G. Peterson and I. H. Marshall (Grand Rapids: Eerdmans, 1998). Moreover, in the Tractaat van de Reformatie der Kerken Kuyper even asserts that the word ekklesia always refers to a local reality, which is yet another distinctive of the Knox-Robinson model. D. B. Knox and D. W. R. Robinson could, nonetheless, be used profitably to critique Kuyper's ecclesiology, if one were to examine the consistency of Kuyper's concept of the church-as-organism qua church, if "gathering" really is of the "essence" of the church. 
In the course of his analysis Thornhill states that the "intrusive voice" of the church has seldom found a sympathetic hearing in the public conversation. ${ }^{20}$ What marks this statement as particularly astute is the way it identifies problematic aspects in connection with the speaker as much as much as it does the speech. It suggests that what makes religion intrusive to Australian sensibilities may well have more to do with the institutional church which has given it voice than the subject matter per se. This possibility may also lie in the background of certain comments made by the Prime Minister of Australia, Kevin Rudd, at the time of the CPX's founding. Rudd noted that there was once "a time in Australia when it was considered impolite to publically discuss matters of religion and politics," but welcomed the founding of the CPX as an organization that held great potential to promote Christian engagement with public life and culture. ${ }^{21}$ If Australian religious journalism has found its non-intrusive voice in the form of the CPX, the organism-institution distinction could well provide a useful heuristic device for the task of discerning why.

One possible explanation for why the CPX has been received as a more welcome partner in the Australian conversation is that the CPX does not transgress the kind of boundaries of natural authority that Kuyper perceived to exist in society. Like Kuyper's church-as-organism, the CPX is identifiable as a discrete entity distinct from any institutional church. Even more significantly, it maintains this identity by recognizing what it is that is distinctive to the speech of the church-as-institution. On this Kuyper is abundantly clear. "Go, teach all nations and baptize them", writes Kuyper, "Teach and baptize, says the founding document of that institution 'Word and Sacrament'-behold the foundational parameters of the design according to which the institution is constructed."22 The proclaimed word of the Gospel and the embodied word of baptism therefore, constitutes the authoritative speech of the church-as-institution. This mode of speaking does not, however, exhaust the church's witness to the Word, nor does it encompass everything that the church ought to say in public. Indeed, one

20 Thornhill, 222.

21 www.publicchristianity.org/images/library/Prime_Ministers_letter.pdf Accessed 15.3.16

22 Abraham Kuyper, Rooted and Grounded: The Church as Organism and Institution (Christian Library Press: Grand Rapids, 2013), 15. 
of Kuyper's favourite metaphors was that of light shining from within a church building onto the world beyond. Kuyper writes, "Though the lamp of the Christian religion only burns within that Institute's walls, it shines out through its windows to areas far beyond, illuminating all the sectors and associations that appear across the wide range of human life and activity." ${ }^{23}$ Thus, it was Kuyper's deeply held conviction that there was a non-institutional dimension to the church's witness to the Word, a mode of speech that is the mother tongue of the church-as-organism.

According to Kuyper then, the church must speak prophetically into every domain, yet in so doing it must speak not as the institutional, but as the organic church. The CPX, likewise, holds the conviction that the church must speak into every domain, yet in a mode and manner that is distinct from its institutional identity. This is reflected in the CPX's tacit acknowledgment of the mode of speech that Kuyper describes as the charter of the church-as-institution. Even though it is an outcome that the CPX warmly welcomes, personal conversion does not constitute one of the primary aims or objectives of its speech. Rather, the CPX considers its commendation of the Gospel as a handmaiden to the proclamation of the institutional church. It seeks to illuminate all the sectors of human life and activity, yet without appeal to the distinctive authority of the churchas-institution. That the CPX restricts its speech in this way to a kind of 'extra mural' witness to the Word, may well account, at least in part, for why its voice is not heard as a challenge to the authority structures of the spheres into which it speaks. By speaking as the church-as-organism the CPX upholds these structures, yet furnishes public debate with a reasoned Christian voice.

The organism-institution distinction therefore, presents the CPX with a very useful heuristic device for reflecting on its warmer reception in the public square. Kuyperian principle in this way holds promise for CPX praxis, but CPX praxis too, at certain points, can fruitfully be used to interrogate Kuyperian principle. One area in particular concerns Kuyper's doctrine of pluriformity.

23 Abraham Kuyper, "Common Grace," in James D. Bratt ed. Abraham Kuyper: A Centennial Reader (Grand Rapids: Eerdmans, 1998), 194. 


\section{The pluriformity of the church in politics}

As a general concept, pluriformity has a long pedigree in Kuyper's thought. Kuyper first took up the theme in a lecture he delivered on $22^{\text {nd }}$ April 1869 entitled, Uniformity: The Curse of Modern Life. ${ }^{24}$ While Kuyper addresses ecclesial pluriformity only briefly, he opines that the Reformation did not make any real advance on the problem of uniformity. "The Reformation resulted in the uniformity of the Christian church being localized ... ecclesiastical unity was broken while ecclesiastical uniformity had only been tempered." ${ }^{25}$ Kuyper would later develop the basic contours of this important statement in his Treatise on the Reformation of the Church. ${ }^{26}$ In this pamphlet Kuyper offers an extended theological defence of multiple denominations, arguing that any ecclesial structures beyond the local congregation held only federative and voluntary significance, as the essence of the church was present fully and sufficiently in the local congregation. On this basis Kuyper could conclude that the multiplication of denominations represented neither a departure from divine ordinance, nor a compromise of the one holy and apostolic church. ${ }^{27}$

While the doctrine of pluriformity is noteworthy for the fact that it offers an answer to the problem of Protestantism, it also holds significance for the relationship between church and State. Kuyper held that Belgic Confession was profoundly mistaken to have affirmed the State's responsibility to uphold sacred ministry and curb false religion. Any such intervention in this regard represented a serious incursion on the church's freedom. Kuyper thus urged his congregation in Amsterdam, "Let the church be free from the state, and thereby correct the enormous mistake committed by Jesus' church fourteen centuries ago to curry the emperor's favour." 28 Kuyper would lead his and other congregations into this freedom in

24 Abraham Kuyper, Eenvormigheid, de vloek van het moderne leven (Amsterdam: H. de Hoogh, 1870).

25 Abraham Kuyper, "Uniformity: The Curse of Modern Life," in James D. Bratt ed. Abraham Kuyper: A Centennial Reader, (Grand Rapids: Eerdmans, 1998), 37.

26 Abraham Kuyper, Tractaat van de reformatie der Kerken (Höveker and Zoon: Amsterdam, 1883).

27 Cf. James D. Bratt, Abraham Kuyper: Modern Calvinist, Christian Democrat (Grand Rapids: Eerdmans, 2013), 151.

28 Kuyper, Rooted and Grounded, 27. 
1886 in the Doleantie, but in so doing Kuyper was fully aware that "the relation of church and state undergoes no stronger change than through the splitting of the one visible church into many churches of different, even partly contradictory confession." ${ }^{29}$ The change may be radical, yet Kuyper believed that ultimately it clarified what was previously opaque. In his Lectures on Calvinism, Kuyper elaborates:

$[\mathrm{T}]$ his system of bringing differences in religious matters under the criminal jurisdiction of the government resulted directly from the conviction that the church of Christ on earth could express itself only in one form and as one institution ... break that one church into fragments, admit that the church of Christ can reveal itself in many forms, in different countries; may, even in the same country, in a multiplicity of institutions; and immediately everything which was deduced from this unity of the visible church drops out of sight. ${ }^{30}$

Kuyper had clearly reflected deeply on the significance pluriformity holds for the church-as-institution. It safeguards the institutional church's freedom and clarifies its relation to the State. What is less clear, however, is whether Kuyper had traced out the implications pluriformity holds for the church-as-organism. In particular, Kuyper seems not to have fully allowed for the fact that a plurality of institutional doctrine and praxis entails a pluriformity beyond the church's institutional identity. Where multiple denominations are allowed to thrive according to their own lifesystems, they will inevitably generate a plurality of visions of the common life. ${ }^{31}$ Kuyper himself, however, seemed reluctant to entertain any space for such diversity. In fact, much of his rhetoric can easily be taken as attempts to impose an alien uniformity on the church-as-organism. Even making allowances for the heat of the moment, statements such as, "remove from your midst all that might contribute to dividing God's people at the ballot box," or "really, they do not understand how by giving their vote to a Liberal ... they are actually voting against their Lord," leave little room for

29 Abraham Kuyper, De Gemeene Gratie 3 vols. (Kampen: Kok, 1931-3), vol. 3, 231-2. Cit. Wood, 145.

30 Kuyper, Lectures on Calvinism, 130.

31 Van der Woude offers a fascinating account of the eventual historical rise of one of these alternatives in "Taming the Beast: The Long and Hard Road to the Christian Social Conference of 1952," Journal of Markets \& Morality 14/2 (2011): 419-444. 
any notion of pluriformity. ${ }^{32}$ For Kuyper it would seem that there was but one vision of the common life that could be allowed to thrive.

It is well worth pondering whether the CPX's reluctance to promote any particular political platform may not in fact represent a clearer recognition of the implications the doctrine of pluriformity holds for the churchas-organism. If pluriformity characterizes the church-as-institution, it necessarily characterizes the church-as-organism as well. As it pertains to the political sphere, pluriformity presupposes a multiplicity of political platforms arising from the multiple construals of the common good. The promotion of any one of these platforms on the part of religious journalism could therefore, amount to the imposition of an alien uniformity on the church. It could be argued that if it claims in any meaningful way to speak for the church, a politically partisan religious journalism inevitably compromises ecclesial pluriformity for the simple reason that no singular political platform can represent the multiplicity of the church-as-organism's visions of the public good. Furthermore, it is far from clear as to whether religious journalism bears any authority to adjudicate between political platforms. If the State does not have the right to adjudicate between church denominations, what right does specifically religious journalism have to adjudicate between political platforms ${ }^{33}$ It is conceivable therefore, that a certain illocutionary restraint ought proceed from the recognition of the church's pluriformity. Religious journalism may well be called to fulfil a prophetic calling in the political sphere, yet if it presumes to speak in any representative capacity, it must temper its speech in such a way that it truly speaks for the church-as-organism in all its pluriformity.

The doctrine of pluriformity thus represents one example whereby CPX praxis stands to be used profitably in the development of Kuyperian principle. The CPX's reluctance to promote particular political platforms presents a stimulus for reconsidering whether Kuyper had fully traced out the implications that the doctrine pluriformity holds for the church-asorganism.

32 Abraham Kuyper, "Maranatha," in James D. Bratt ed. Abraham Kuyper: A Centennial Reader, (Grand Rapids: Eerdmans, 1998), 226, 218.

33 Of course this raises the problem of what there is to prevent pluriformity morphing into pluralism, but that question is well beyond the scope of this discussion. 


\section{Conclusion}

The points of contact that can be observed between the Centre for Public Christianity and the journalistic legacy of Abraham Kuyper thus mutually inform religious journalism in Australia and Kuyperian public theology. On the one hand, Kuyper's organism-institution distinction presents an organization like the CPX with a conceptual framework for exploring its rationale and aims and why it might be that it is perceived as a more welcome participant in the Australian public conversation. On the other hand, the CPX's attitude towards specific political agendas hold special interest for Kuyper's doctrine of pluriformity and the illocutionary restraint this principle potentially places on religious journalism. The momentous cultural, technological, and political differences that stand between Kuyper's Netherlands and twenty-first century Australia compound the difficulties of such reflection, yet they also redouble its significance. The praxis of an organization like the $C P X$, which navigates the uncharted waters of the secularist future Kuyper had anticipated, presents a helpful stimulus to the re-visioning of Kuyperian principle and where it can demonstrate its relevance beyond the bounds of its Neo-Calvinistic origins, Abraham Kuyper's public theology stands to make a valuable contribution to the kind of global theology of which an organization like the CPX has need. An organization like the CPX can, however, navigate these waters in good hope. Although religious journalism occupies a very limited space in Australian mainstream media, the CPX stands neither to be completely ignored nor completely silenced. Australians have capitulated neither to the shrill cries of the new Atheism nor fear of Islamic fundamentalism. The (mostly) benign indifference toward religion that has characterized Australia from its beginnings still holds sway. As yet the shy hope remains.

\section{Bibliography}

Bacote, Vincent 2005. The Spirit in Public Theology: Appropriating the Legacy of Abraham Kuyper. Eugene: Wipf and Stock.

Berends, Willem. “Tertiary Education in Australia: Part II.” Christian Higher Education, 11/5, (2012): 303-309.

Black, Alan W. “The Sociology of Religion in Australia.” Sociological Analysis 51 Suppl. (1990): 27-41. 
Bolt, Peter 1998. "Mission and Witness." In Witness to the Nations: The Theology of Acts, edited by DG Peterson and IH Marshall. Grand Rapids: Eerdmans.

Bratt, James D 2013. Abraham Kuyper: Modern Calvinist, Christian Democrat. Grand Rapids: Eerdmans.

Bratt, James D. "Passionate About the Poor: The Social Attitudes of Abraham Kuyper." Journal of Markets and Morality 5/1 (2002): 35-44.

Bouma, Gary 2006. Australian Soul: Religion and Spirituality in the Twenty-First Century. Cambridge: Cambridge University Press.

Clark, Manning 1985. “Heroes.” In Australia: The Daedalus Symposium, edited by S Graubard. London: Angus and Robertson.

Carey, Hilary, Breward, Ian, O’Brien, Anne, Rutland, Suzanne and Thompson, Roger. "Australian Religion Review, 1980-2000, Part 1: Surveys, Bibliographies and Religions Other Than Christianity." The Journal of Religious History 24/3 (2000): 296-305.

De Bruijne, Ad. “Colony of Heaven: Abraham Kuyper’s Ecclesiology in the Twenty-First Century." Journal of Markets and Morality 17/2 (2014): 445-90.

Frame, Tom 2009. Losing My Religion: Unbelief in Australia. Sydney: UNSW Press.

Kuyper, Abraham 1899. Calvinism: Six Stone-Lectures. Edinburgh: T \& T Clark.

- 1998. “Common Grace.” In Abraham Kuyper: A Centennial Reader, edited by James D Bratt. Grand Rapids: Eerdmans.

- De Gemeene Gratie 3 vols. Kampen: Kok, 1931-3.

- 1870, 1998. Eenvormigheid, de vloek van het moderne leven. Amsterdam: H. de Hoogh, translated. "Uniformity: The Curse of Modern Life." In Abraham Kuyper: A Centennial Reader, edited by James D. Bratt. Grand Rapids: Eerdmans, 1998.

- 1998. "Maranatha." In Abraham Kuyper: A Centennial Reader, edited by James D Bratt. Grand Rapids: Eerdmans.

- 2013. Rooted and Grounded: The Church as Organism and Institution. Christian Library Press: Grand Rapids. 
- 1833. Tractaat van de Reformatie der Kerken. Höveker and Zoon: Amsterdam.

Marty, Martin E. “Talking About Religion Down Under.” The Christian Century, 106/23 (1989): 708-9.

Melleuish, Gregory. "A Secular Australia? Ideas, Politics and the Search for Moral Order in Nineteenth and Early Twentieth Century Australia." The Journal of Religious History, 38/3 (2014): 398-412.

Millikan, Douglas 1982. "Christianity and Australian Identity." In The Shape of Belief, edited by David Harris, Dorothy Hynd, and Douglas Millikan. Homebush: Lander.

Peterson, David. “The 'Locus' of the Church-Heaven or Earth?” Churchman 112/3 (1998): 199-213.

Piggin, Stuart. "Power and Religion in a Modern State: Desecularisation in Australian history," The Journal of Religious History 38/3 (2014): $320-40$.

Rowe, David. "Obituary for the newspaper? Tracking the tabloid," Journalism 12/4 (2011): 449-66.

Strange, Daniel. "Rooted and Grounded? The Legitimacy of Abraham Kuyper's Distinction between Church as Institute and Church as Organism, and Its Usefulness in Constructing an Evangelical Public Theology," Themelios 40/3 (2015): 429-45.

Tiffen, Rodney. “Australian Journalism,” Journalism 10/3 (2009): 384-6.

Thornhill, John 1992. Making Australia: Exploring Our National Conversation. Newtown: Millennium, 1992.

Van Der Woude \& Roelof E. "Taming the Beast: The Long and Hard Road to the Christian Social Conference of 1952," Journal of Markets \& Morality 14/2 (2011): 419-444.

Wood, John Halsey 2013. Going Dutch in the modern age : Abraham Kuyper's struggle for a free church in the nineteenth-century Netherlands. New York: Oxford University Press.

Zijlstra, Albertus 1937. “Dr Kuyper als jouranlist.” In Dr. A. Kuyper 18371937, edited by LWG Scholten, C Smeenk and J Waterink. Kampen: Kok. 